\title{
Low replacement doses of thyroxine during food restriction restores type 1 deiodinase activity in rats and promotes body protein loss
}

\author{
Renata Lopes Araujo, Bruno Moulin de Andrade, Álvaro Souto Padron de Figueiredo, Monique Leandro da \\ Silva, Michelle Porto Marassi, Valmara dos Santos Pereira, Eliete Bouskela ${ }^{1}$ and Denise P Carvalho \\ Laboratório de Fisiologia Endócrina do Instituto de Biofísica Carlos Chagas Filho, Universidade Federal do Rio de Janeiro, Rio de Janeiro, CEP 21949-900, Brazil \\ ${ }^{1}$ Laboratório de Pesquisas em Microcirculação, Instituto de Biologia Roberto Alcantara Gomes, Universidade do Estado do Rio de Janeiro, Rio de Janeiro, \\ CEP 20550013 Brazil \\ (Correspondence should be addressed to D P Carvalho; Email: dencarv@biof.ufrj.br)
}

\begin{abstract}
During food restriction, decreased basal metabolic rate secondary to reduced serum thyroid hormones levels contributes to weight loss resistance. Thyroxine $\left(\mathrm{T}_{4}\right)$ and $3,3^{\prime}, 5$-triiodothyronine $\left(\mathrm{T}_{3}\right)$ administration during caloric restriction produce deleterious side effects; however, the administration of physiological doses of $\mathrm{T}_{4}$ during food restriction has never been evaluated. The aim of this study was to analyze the effects of low replacement doses of $\mathrm{T}_{4}$ in Wistar rats subjected to $40 \%$ food restriction. Food restriction for 30 days led to significantly reduced liver type 1 deiodinase activity, serum TSH, leptin, $\mathrm{T}_{4}$, $\mathrm{T}_{3}$, metabolic rate, and body mass. The significant reduction in hepatic deiodinase activity found during food restriction was normalized in a dose-dependent manner by $\mathrm{T}_{4}$ replacement, showing that decreased type 1 deiodinase (D1) activity is
\end{abstract}

secondary to decreased serum thyroid hormone levels during caloric restriction. The lowest replacement dose of $\mathrm{T}_{4}$ did not normalize resting metabolic rate, but was able to potentiate the effects of food restriction on carcass fat loss and did not spare body protein. The highest dose of $\mathrm{T}_{4}$ produced a normalization of daily oxygen consumption and determined a significant reduction in both carcass fat and protein content. Our results show that serum $\mathrm{T}_{4}$ normalization during food restriction restores serum $\mathrm{T}_{3}$ and liver $\mathrm{D} 1$ activity, while body protein is not spared. Thus, decreased serum $\mathrm{T}_{4}$ during caloric restriction corresponds to a protective mechanism to avoid body protein loss, highlighting the importance of other strategies to reduce body mass without lean mass loss.

Journal of Endocrinology (2008) 198, 119-125

\section{Introduction}

Moderate reduction in caloric intake has well-known systemic consequences, including weight loss and a decrease in fat mass; however, homeostatic mechanisms impair further weight loss after long periods of food restriction, such as the decrease in basal metabolic rate (Ravucin et al. 1985, Rosenbaum et al. 2002). The responses to food restriction have been well documented in a number of species, including humans (Kelley et al. 1993), monkeys (Kemnitz et al. 1994), rats (Dean et al. 1998), and mice (Harris et al. 1994). Thyroid hormones are the predominant regulators of basal metabolic rate and their serum levels are reduced during caloric deprivation (Vagenakis et al. 1977, Scriba et al. 1979, Kinlaw et al. 1985, Douyon \& Schteingart 2002). Since thyroid hormones seem to play a crucial role in energy homeostasis by regulating both energy intake and expenditure, analogs of these hormones have long been considered to be potential drugs for controlling body mass (Oh \& Kaplan 1994, Moreno et al. 2003, Lanni et al. 2005, Villicev et al. 2007).

Decreased thyroid function seems to be related to impaired thyrotropin-releasing hormone (TRH) and thyroid-stimulating hormone (TSH) secretion (Ahima 2000, Krotkiewski 2000), and to changes in the peripheral deiodination of thyroid hormones (Bianco et al. 2002). Three iodothyronine deiodinases have been identified and characterized in different tissues. Type 1 deiodinase (D1) is found in liver, kidney, and thyroid gland and catalyzes both the outer and inner ring deiodination of iodothyronines, while types 2 (D2) and 3 (D3) deiodinases act exclusively as outer and inner ring deiodinases respectively (Bianco et al. 2002). Previous studies have shown that liver and pituitary D1 activities are significantly decreased during fasting in rats. However, since the main positive regulator of liver and kidney D1 activity is $\mathrm{T}_{3}$ (Bianco et al. 2002, Aceves et al. 2003), which is also reduced under caloric restriction, it is difficult to establish whether decreased D1 activity is related to a direct effect of fasting, per se, or secondary to serum thyroid hormone reduction (St Germain \& Galton 1985, O’Mara et al. 1993, Aceves et al. 2003).

Although it has long been recognized that thyroid hormones modify body mass composition, these previous studies have used high $\mathrm{T}_{4}$ doses $(25-250 \mu \mathrm{g} / 100 \mathrm{~g}$ body mass; Aranda et al. 1972, Okajima \& Ui 1979, Müller \& Seitz 1980), which lead to thyrotoxicosis and several deleterious effects on the organism such as protein loss, heart hypertrophy, and arrhythmias (Klein \& Ojamaa 2001). 
However, the replacement of a low physiological dose of $\mathrm{T}_{4}$ during food restriction in normal rats has not been reported so far. The lowest $T_{4}$ dose found in the literature has been tested by Burini et al. (1981) in a previous report using thyroidectomized rats under food restriction $(2 \mu \mathrm{g} \mathrm{T} / 4100 \mathrm{~g}$ b.w.), but apart from using thyroidectomized rats, no oxygen consumption or deiodinase activities have been evaluated. Some other previous reports describe the effects of $\mathrm{T}_{3}$ administration on food-restricted (FR) obese patients, and the great majority uses a high $\mathrm{T}_{3}$ dose (Bray et al. 1973, Wilson \& Lamberts 1981). On the other hand, the effects of low replacement doses of $\mathrm{T}_{4}$ during a period of food restriction have not been studied so far, although an early report of leptin replacement and serum $\mathrm{T}_{4}$ restoration indicates beneficial actions in humans under caloric restriction (Rosenbaum et al. 2002).

In the present paper, our aim was to restore serum $\mathrm{T}_{4}$ levels during food restriction in male Wistar rats in order to determine whether physiological $\mathrm{T}_{4}$ replacement restores liver and kidney type 1 deiodinase activities, resting metabolic rate (RMR), and body mass composition.

\section{Materials and Methods}

\section{Animals}

Adult male Wistar rats were housed at controlled temperature $\left(23^{\circ} \mathrm{C}\right)$ with daily exposure to a $12 \mathrm{~h}$ light: $12 \mathrm{~h}$ darkness cycle and free access to water and standard rat chow. This investigation conforms to the Guide for the Care and Use of Laboratory Animals published by the US National Institutes of Health (NIH Publication No.85-23, revised 1996) and was approved by the institutional animal welfare committee. All animals were individually housed for a 1-week acclimation period and baseline control food intake was assessed.

\section{0 days food restriction}

Food intake was assessed over 7 days for each rat by offering food ad libitum and measuring the quantity consumed. After this period, the ad libitum (control - C) group had free access to food, and the FR group received $60 \%$ of their individual baseline intake for 30 days, so that the food was $40 \%$ restricted. During the food restriction period, all rats were weighed every 2 days.

\section{$T_{4}$ treatment}

After 15 days of the beginning of food restriction, control (C) and FR rats were randomly assigned to start chronic treatment by daily single s.c. injections of ( $\mathrm{L}-\mathrm{T}_{4}$ Sigma) or saline $(0 \cdot 9 \%$ $\mathrm{NaCl}$ ). The use of $\mathrm{T}_{4}$ instead of $\mathrm{T}_{3}$ is of physiological relevance, since $T_{4}$ is the major product of the thyroid gland and its secretion is decreased during food restriction. $\mathrm{T}_{4}$ treatment protocol was done as follows: $1 \cdot 0 \mu \mathrm{g} / 100 \mathrm{~g}$ b.w. (FR $\mathrm{T}_{4}(1)$ ), which has been used to restore the euthyroid status in hypothyroid animals (Ortiga-Carvalho et al. 1996), and a dose of $5.0 \mu \mathrm{g} / 100 \mathrm{~g}$ b.w. (FR $\mathrm{T}_{4}$ (5)). $\mathrm{T}_{4}$ administration was conducted for the last 15 days of experiment, every $1000 \mathrm{~h}$ for all groups of animals. The animals were killed $24 \mathrm{~h}$ after the last $\mathrm{T}_{4}$ administration by decapitation, and blood was collected from the trunk. Serum was obtained after centrifugation of blood at $1000 \mathrm{~g}$ for $20 \mathrm{~min}$ and stored at $-20^{\circ} \mathrm{C}$ until specific RIA (TSH, $\mathrm{T}_{3}, \mathrm{~T}_{4}$ and leptin). Liver and kidney tissue samples were dissected out and stored at $-70{ }^{\circ} \mathrm{C}$ until processing for D1 activity.

\section{Body composition}

Body composition (fat and protein) was determined by carcass analysis, as previously described (Toste et al. 2006). The retroperitoneal and epididymal fats were completely removed, weighed for evaluation of central adiposity and discarded. The total carcass protein concentrations were determined by the method of Lowry et al. (1951). The carcass results were expressed as $\mathrm{g} / 100 \mathrm{~g}$ carcass. The retroperitoneal and epididymal fats were weighted and expressed as $\mathrm{g} / 100 \mathrm{~g}$ b.w.

\section{Resting metabolic rate}

RMR was measured using open-circuit indirect calorimetry during $24 \mathrm{~h}$, after 30 days of experimental time. The rats were individually placed in a respiration chamber $(25 \times 25 \times$ $15 \mathrm{~cm}$ ), air flow was maintained constant at $500 \mathrm{ml} / \mathrm{min}$ by a mass flow controller (Sable System International, Las Vegas, $\mathrm{NV}$, USA). Oxygen was measured using an $\mathrm{O}_{2}$ analyzer (Sable System International). Oxygen consumption was recorded at $15 \mathrm{~min}$ intervals and the results were expressed in $\mathrm{LO} 2 / \mathrm{kg}$ per h. To avoid disruption caused by an adaptation to the chamber, the first $6 \mathrm{~h}$ were excluded from the analyses.

\section{Serum TSH, leptin, and total $T_{3}$ and $T_{4}$}

Serum TSH levels were evaluated by a specific RIA obtained from the National Institute of Diabetes, Digestive and Kidney Diseases (NIDDK, Bethesda, MD, USA), and expressed in terms of the reference preparation 2 (RP-2). Intra- and interassay coefficients of variation were $7 \cdot 7$ and $6.5 \%$ respectively and the sensitivity was $0.50 \mathrm{ng} / \mathrm{ml}$.

Serum total $\mathrm{T}_{3}$ and $\mathrm{T}_{4}$ concentrations were measured using commercial RIA kits ( $\mathrm{T}_{3}$ : DSL -3100 Active, sensitivity of $4 \cdot 3 \mathrm{ng} / \mathrm{dl}$, inter- and intra-assay coefficients of variation varied from $4 \cdot 2$ to 6.0 and 5 to $6.5 \%$ respectively; $\mathrm{T}_{4}$ : DSL 3200 Active, sensitivity of $0.4 \mu \mathrm{g} / \mathrm{dl}$, inter- and intra-assay coefficients of variation varied from $7 \cdot 1$ to $7 \cdot 4$ and $2 \cdot 9$ to $5 \cdot 1 \%$ respectively; DSL, TX, USA), based on the presence of specific antibodies adhered to the internal surface of propylene tubes. Rat hormone-stripped serum was used for standard curves of total $\mathrm{T}_{4}, \mathrm{~T}_{3}$, and TSH.

Serum leptin concentrations were measured using a specific RIA for rat leptin obtained from the Linco Research Company (St Charles, MO 63304, USA). The kit uses 
Table 1 Body weight and composition of control (C) and food-restricted (FR) rats with or without thyroxine $\left(\mathrm{T}_{4}\right)$ replacement. Values are expressed as mean \pm S.E.M. of at least ten animals per group from three to five experiments

\begin{tabular}{|c|c|c|c|c|c|c|}
\hline & $\mathrm{BW}_{\mathrm{i}}$ & $B W_{f}$ & Carcass protein & Retroperitoneal fat & Epididymal fat & Carcass fat \\
\hline Control (C) & $255 \pm 8 \cdot 87$ & $325 \pm 8 \cdot 54$ & $4 \cdot 4 \pm 0 \cdot 60$ & $1 \cdot 5 \pm 0 \cdot 15$ & $1 \cdot 3 \pm 0 \cdot 05$ & $15 \cdot 0 \pm 1 \cdot 27$ \\
\hline $\mathrm{C}+\mathrm{T}_{4}(1)$ & $256 \pm 7 \cdot 95$ & $316 \pm 7 \cdot 37$ & $3 \cdot 3 \pm 0 \cdot 35$ & $1 \cdot 6 \pm 0 \cdot 27$ & $1 \cdot 5 \pm 0 \cdot 20$ & $12 \cdot 9 \pm 1 \cdot 32$ \\
\hline $\mathrm{C}+\mathrm{T}_{4}(5)$ & $287 \pm 19 \cdot 64$ & $342 \pm 13 \cdot 43$ & $2 \cdot 6 \pm 0 \cdot 17^{+}$ & $1 \cdot 6 \pm 0 \cdot 10$ & $1 \cdot 8 \pm 0.08$ & $15 \cdot 4 \pm 1 \cdot 31$ \\
\hline Food restriction (FR) & $266 \pm 6 \cdot 96$ & $236 \pm 5 \cdot 19 *$ & $5 \cdot 3 \pm 0 \cdot 46$ & $0 \cdot 7 \pm 0 \cdot 09^{*}$ & $0.9 \pm 0.09 *$ & $13 \cdot 1 \pm 0 \cdot 84$ \\
\hline $\mathrm{FR}+\mathrm{T}_{4}(1)$ & $271 \pm 6 \cdot 76$ & $236 \pm 5 \cdot 81^{*}$ & $2 \cdot 8 \pm 0 \cdot 47^{+}$ & $0 \cdot 6 \pm 0 \cdot 22 *$ & $1 \cdot 1 \pm 0 \cdot 27^{*}$ & $8 \cdot 8 \pm 1 \cdot 48^{\ddagger}$ \\
\hline $\mathrm{FR}+\mathrm{T}_{4}(5)$ & $284 \pm 10 \cdot 17$ & $220 \pm 8 \cdot 65^{*}$ & $2 \cdot 6 \pm 0.53^{+}$ & $0 \cdot 3 \pm 0 \cdot 09^{*}$ & $0 \cdot 6 \pm 0 \cdot 16^{*}$ & $8 \cdot 3 \pm 0 \cdot 55^{\ddagger}$ \\
\hline
\end{tabular}

All fat compartments are expressed as g/100 g of b.w. BW $\mathrm{B}_{\mathrm{i}}$, initial body weight; $\mathrm{BW}_{\mathrm{f}}$, final body weight. Control with $\mathrm{T}_{4}$ replacement $(1 \mu \mathrm{g} / 100 \mathrm{~g}$ body weight $)-\mathrm{C}+$ $\mathrm{T}_{4}(1)$, and control with thyroxine replacement $(5 \mu \mathrm{g} / 100 \mathrm{~g}$ body weight $)-C+\mathrm{T}_{4}(5)$. Food restriction with thyroxine replacement $(1 \mu \mathrm{g} / 100 \mathrm{~g} \mathrm{body}$ weight $)-\mathrm{FR}+\mathrm{T}_{4}$ (1), and food restriction with $\mathrm{T}_{4}$ replacement $\left(5 \mu \mathrm{g} / 100 \mathrm{~g}\right.$ body weight) $-\mathrm{FR}+\mathrm{T}_{4}$ (5). Carcass parameters are expressed as g/100 g carcass; retroperitoneal and epididymal fats as $g / 100$ g body weight. ${ }^{*} P<0.05$ versus controls treated or not with $\mathrm{T}_{4},{ }^{\dagger} P<0.05$ versus $\mathrm{FR}$ and control; ${ }^{\ddagger} P<0 \cdot 05$ versus controls treated or not with $\mathrm{T}_{4}$ and FR.

${ }^{125}$ I-labeled rat leptin and a rat leptin antiserum to determine the level of serum leptin by the double antibody/polyethylene glycol (PEG) technique. Intra- and inter-assay coefficients of variation were $3 \cdot 3-6 \cdot 8$ and $4 \cdot 1-2 \cdot 0 \%$ respectively and the sensitivity was $0.50 \mathrm{ng} / \mathrm{ml}$ using $100 \mu \mathrm{l}$ sample size.

All the procedures were carried out following the recommendations as given in the kits.

\section{Deiodinase analyses}

Type 1 iodothyronine deiodinase activity was evaluated as previously described by our group (Fortunato et al. 2006) and based on Berry et al. (1991). In short, tissue (liver or kidney) samples of $25 \mathrm{mg}$ were homogenized in $1 \mathrm{ml}$ of $0 \cdot 1 \mathrm{M}$ sodium phosphate buffer containing $1 \mathrm{mM}$ EDTA, $0 \cdot 25 \mathrm{M}$ sucrose, and $10 \mathrm{mM}$ dithiothreitol (pH 6.9). Homogenates (30 $\mu \mathrm{g}$ protein from liver or kidney) were incubated in a water bath in duplicate for $1 \mathrm{~h}$ at $37^{\circ} \mathrm{C}$ with $1 \mu \mathrm{M} \mathrm{rT}$ (Sigma), equal volumes of ${ }^{125} \mathrm{I} \mathrm{rT}_{3}$ (Perkin-Elmer Life Sciences, Boston, MA, USA) previously purified using sephadex LH20 , and $10 \mathrm{mM}$ dithiothreitol in $100 \mathrm{mM}$ potassium phosphate buffer containing $1 \mathrm{mM}$ EDTA ( $\mathrm{pH}$ 6.9) in a reaction volume of $300 \mu \mathrm{l}$. Blank incubations were carried out in the absence of protein. The reaction was stopped after incubation at $4{ }^{\circ} \mathrm{C}$ followed by the addition of $100 \mu \mathrm{l}$ fetal bovine serum (Cultilab, Campinas, Brazil) and $200 \mu 1$ trichloroacetic acid $(50 \%, v / v)$. The samples were centrifuged at $8000 \mathrm{~g}$ for $3 \mathrm{~min}$, and the supernatant was collected for measurement of ${ }^{125} \mathrm{I}$ liberated during the deiodination reaction.

Protein concentration in the homogenates was measured by the Bradford method (Bradford 1976), after incubation of homogenates with $\mathrm{NaOH}(2 \cdot 5 \mathrm{M})$. The specific enzyme activity was expressed as picomoles of $\mathrm{rT}_{3}$ deiodinated/min/ mg protein.

\section{Statistical analyses}

Results were expressed as mean \pm s.E.M. Body mass, fat and protein content, total serum $\mathrm{T}_{3}, \mathrm{~T}_{4}, \mathrm{TSH}$ and leptin concentrations, deiodinase activity, and oxygen consumption were analyzed by two-way ANOVA, followed by Bonferroni multiple comparison tests. Statistical analyses were done using the software Graphpad Prism (version 4, Graphpad Software, Inc., San Diego, CA, USA). The differences were considered significant when $P<0 \cdot 05$.

\section{Results}

Body composition - mass, fat, and protein contents

Final body mass was lower in FR compared with $\mathrm{C}$ groups (Table 1, $P<0 \cdot 001$ ), and the two doses of $\mathrm{T}_{4}$ did not produce any further body mass change (Table 1 ).

Retroperitoneal and epididymal fat mass were significantly lower in FR compared with C groups (Table 1, $P<0 \cdot 001$ ), and no further reduction in these fat compartments were observed with both $\mathrm{T}_{4}$ doses (Table 1). On the other hand, carcass fat was not affected by FR per se, while the two doses of $\mathrm{T}_{4}$ significantly decreased carcass fat mass $(P<0 \cdot 01)$. These results show that $T_{4}$ effects on adipose tissue depends on the fat compartment analyzed.

Carcass protein content was not significantly different between C and FR groups, demonstrating that $40 \%$ food deprivation for 30 days did not affect body protein content. However, exogenous $\mathrm{T}_{4}$ administration during food restriction produced a significant decrease in body protein content with the use of either the lowest $\left(F R T_{4}(1)\right)$ or the highest (FR $\mathrm{T}_{4}$ (5)) $\mathrm{T}_{4}$ doses (Table 1, $P<0 \cdot 001$ ). We have also observed a significant decrease in carcass protein content in control rats fed ad libitum and treated with the highest dose of $\mathrm{T}_{4}$ (Table 1).

\section{Serum TSH, leptin, and total $T_{3}$ and $T_{4}$}

Serum TSH and leptin concentrations were significantly reduced $(P<0 \cdot 001)$ after 30 days of food restriction, and remained low in the $\mathrm{T}_{4}$ replaced groups $\left(\mathrm{FR} \mathrm{T}_{4}(1)\right.$ and (5); Table 2). 
Table 2 Serum thyroid-stimulating hormone (TSH), leptin, total tri-iodothyronine $\left(\mathrm{T}_{3}\right)$ and thyroxine $\left(\mathrm{T}_{4}\right)$ of control $(\mathrm{C})$ and food-restricted ( $\left.\mathrm{FR}\right)$ Wistar rats with or without $\mathrm{T}_{4}$ replacement. Values are expressed as mean \pm s.E.M. of at least ten animals per group from three to five experiments

\begin{tabular}{|c|c|c|c|c|}
\hline & $\mathbf{T}_{\mathbf{3}}(\mathrm{ng} / \mathrm{dl})$ & $\mathbf{T}_{\mathbf{4}}(\mu \mathrm{g} / \mathrm{dl})$ & TSH (ng/ml) & Leptin $(\mathrm{ng} / \mathrm{ml})$ \\
\hline Control (C) & $87 \cdot 1 \pm 22 \cdot 84$ & $4 \cdot 7 \pm 1 \cdot 3$ & $1 \cdot 5 \pm 0 \cdot 78$ & $4 \cdot 6 \pm 2 \cdot 38$ \\
\hline $\mathrm{C}+\mathrm{T}_{4}(1)$ & $130 \cdot 4 \pm 40 \cdot 46^{*}$ & $7 \cdot 2 \pm 1 \cdot 9 *$ & $1 \cdot 0 \pm 0 \cdot 20^{\dagger, \mathrm{a}}$ & $4 \cdot 1 \pm 2 \cdot 18$ \\
\hline $\mathrm{C}+\mathrm{T}_{4}(5)$ & $190 \cdot 7 \pm 46 \cdot 53^{+}$ & $12 \cdot 0 \pm 2 \cdot 8^{\dagger}$ & $<0 \cdot 5$ & $4 \cdot 9 \pm 2 \cdot 40$ \\
\hline Food restriction (FR) & $49 \cdot 1 \pm 25 \cdot 93^{+}$ & $3 \cdot 5 \pm 1 \cdot 1^{*}$ & $<0.5$ & $0 \cdot 99 \pm 0 \cdot 09^{\ddagger}$ \\
\hline $\mathrm{FR}+\mathrm{T}_{4}(1)$ & $71 \cdot 4 \pm 38 \cdot 52$ & $7 \cdot 4 \pm 2 \cdot 6^{\dagger}$ & $<0.5$ & $0 \cdot 94 \pm 0 \cdot 14^{\neq, \S}$ \\
\hline $\mathrm{FR}+\mathrm{T}_{4}(5)$ & $56 \cdot 3 \pm 39 \cdot 42^{*}$ & $10 \cdot 0 \pm 5 \cdot 3^{+}$ & $<0 \cdot 5$ & $1 \cdot 48 \pm 0 \cdot 65^{\neq, \S}$ \\
\hline
\end{tabular}

Serum concentrations in control (C), control with $\mathrm{T}_{4}$ replacement of $1 \mu \mathrm{g} / 100 \mathrm{~g}$ body weight $-\mathrm{C}+\mathrm{T}_{4}(1)$ or $5 \mu \mathrm{g} / 100 \mathrm{~g}$ body weight $-\mathrm{C}+\mathrm{T}_{4}(5)$; food restriction (FR), food restriction with $\mathrm{T}_{4}$ replacement $1 \mu \mathrm{g} / 100 \mathrm{~g}$ body weight $-\mathrm{FR}+\mathrm{T}_{4}(1)$ or $5 \mu \mathrm{g} / 100 \mathrm{~g}$ body weight $-\mathrm{FR}+\mathrm{T}_{4}(5) .{ }^{*} P<0 \cdot 01$ or ${ }^{\dagger} P<0 \cdot 001$ versus control; ${ }^{\ddagger} P<0 \cdot 001$ versus control treated or not with $\mathrm{T}_{4}$.

an five to six animals serum TSH or leptin were below the limit of detection.

Serum $T_{4}$ and $T_{3}$ concentrations were significantly reduced after 30 days of food restriction (Table 2), and increased in FR rats treated with the lowest dose of $\mathrm{T}_{4}$ (Table 2). Serum $\mathrm{T}_{4}$ levels significantly increased in $\mathrm{FR} \mathrm{T}_{4}(5)$ in relation to $\mathrm{FR} \mathrm{T}_{4}(1)$ and $\mathrm{FR}$ (Table 2); however, serum $\mathrm{T}_{3}$ did not increase significantly in the $\mathrm{FR}_{4}$ (5) (Table 2).

\section{Resting metabolic rate}

Figure 1 summarizes the results collected over a 24-h period of time. The results were plotted as mean oxygen consumption and were analyzed as the area under the curve. There was a $45 \%$ reduction in total oxygen consumption when FR was compared with the control group (Fig. 1, $P<0 \cdot 05$ ). The lowest dose of $\mathrm{T}_{4}$ did not normalize $\mathrm{RMR}$, but treatment with the highest $\mathrm{T}_{4}$ dose restored $\mathrm{RMR}$ to control values, suggesting that the reduction in basal metabolism observed during food deprivation is, in part, dependent on the decreased serum thyroid hormone concentrations.

\section{Deiodinase activity}

Liver type 1 iodothyronine deiodinase activity was significantly reduced after 30 days of food restriction (Fig. 2A, $P<0 \cdot 05)$. When the groups submitted to food restriction were treated with exogenous $T_{4}, D 1$ activity increased in a dose-dependent manner (Fig. 2A, $P<0 \cdot 001)$.

Kidney D1 activity was not significantly different after 30 days of food restriction (Fig. 2B). Treatment with the lowest dose of $\mathrm{T}_{4}$ in $\mathrm{FR}$ rats did not change the enzyme activity and only the highest dose of $\mathrm{T}_{4}$ led to a significant increase in kidney D1 activity when compared with the FR group (Fig. 2B, $P<0 \cdot 01$ ).

\section{Discussion}

We show herein that 30 days of food restriction leads to reduction in serum $\mathrm{TSH}, \mathrm{T}_{4}, \mathrm{~T}_{3}$, and leptin, which parallel the reduction in body mass, retroperitoneal, and epididymal fat compartments; however, no changes were observed on carcass fat and protein contents. Interestingly, the replacement of $\mathrm{T}_{4}$ to $\mathrm{FR}$ groups with a dose just able to normalize serum $\mathrm{T}_{4}$ did not affect body mass and retroperitoneal and epididymal fats, although significant body protein and fat carcass loss were detected. These results differ from studies that described significant modifications in body mass when animals and humans were treated with higher doses of $\mathrm{T}_{4}$ or triiodothyronine (25-250 $\mathrm{g} / 100 \mathrm{~g}$ body mass). Bray et al. (1973) evaluated the effect of tri-iodothyronine $(150 \mu \mathrm{g} /$ day $)$ in combination with a liquid formula diet $(900 \mathrm{kcal} /$ day $)$ and showed that $\mathrm{T}_{3}$ produces a higher body weight loss. Wilson \& Lamberts (1981) also showed a significant reduction on body mass using $\mathrm{T}_{3}(25 \mu \mathrm{g} /$ day $)$ in obese patients during drastic
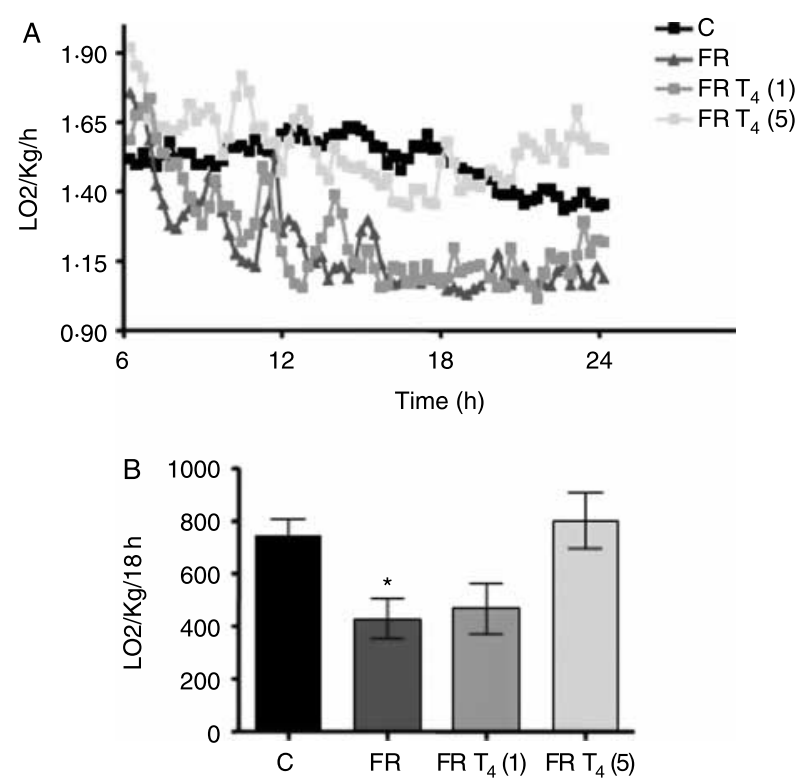

Figure 1 Resting metabolic rate in control (C) and food-restricted (FR) Wistar rats with saline (dark gray bar) or $\mathrm{T}_{4}$ replacement ( $1 \mu \mathrm{g} / 100 \mathrm{~g}$ b.w., gray bar and $5 \mu \mathrm{g} / 100 \mathrm{~g}$ b.w., light gray bar).

(A) Oxygen consumption during $18 \mathrm{~h}(\mathrm{C} ; n=20 \mathrm{FR} ; n=7 \mathrm{FR} 1 ; n=4$ FR $5 ; n=5$ ) and (B) Area under the curve. ${ }^{*} P<0.05$ versus control. 


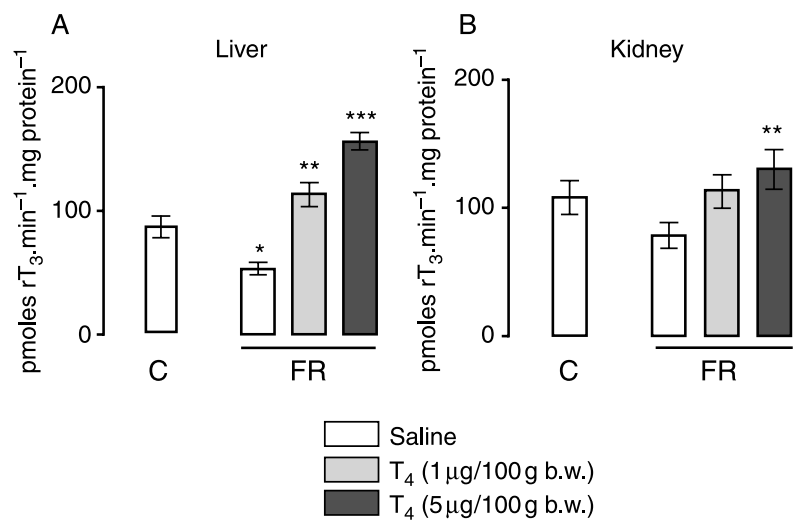

Figure 2 Type 1 iodothyronine deiodinase (D1) activity in control (C) and $40 \%$ food-restricted (FR) rats with saline (white bar) or $\mathrm{T}_{4}$ replacement $(1 \mu \mathrm{g} / 100 \mathrm{~g}$ b.w, light gray bar and $5 \mu \mathrm{g} / 100 \mathrm{~g}$ b.w, dark gray bar). (A) D1 Hepatic (C, $n=8 ; \mathrm{FR}, n=13 ; \mathrm{FR} \mathrm{T}_{4}(1), n=12$; $\left.\mathrm{FR} \mathrm{T}_{4}(5), n=15\right)$ and (B) D1 Kidney (C, $n=9 ; \mathrm{FR}, n=15 ; \mathrm{FR} \mathrm{T}_{4}(1)$, $\left.n=12 ; \mathrm{FR} \mathrm{T}_{4}(5), n=13\right)$. Results are shown as mean \pm S.E.M. ${ }^{*} P<0 \cdot 05$ versus control; ${ }^{* *} P<0.01$ versus control and FR; $* * * P<0 \cdot 001$ versus all the other groups.

calorie restriction. These differences could be related to the fact that in these studies a large dose of $\mathrm{T}_{3}$ was used, while we used a low dose of $\mathrm{T}_{4}$. Our results also show the concomitant reduction of serum $\mathrm{T}_{4}$ and $\mathrm{RMR}$ during food restriction. Also, Moreno et al. (2003) showed that a single dose of $T_{3}$ $(25 \mu \mathrm{g} /$ day $)$ to fasted rats restores uncoupling protein-3, uncoupling by regulating the levels of coenzyme $\mathrm{Q}$. The changes in metabolism created by the association of two inverse energy conditions: food deprivation (decreased energy) and $\mathrm{T}_{4}$ administration (increased energy) led to a significant decrease in body protein compartment, showing that the reduction in RMR during FR could represent a mechanism of physiological protection against body protein loss, as previously suggested (Gardner et al. 1979).

The effects of food restriction on serum TSH, leptin, and thyroid hormones were strikingly similar to those previously described by other authors (Salih et al. 1993, Gazdag et al. 1999, Davidson et al. 2002). The mechanisms that explain $\mathrm{T}_{4}$ reduction during calorific restriction have been partially defined. Serum leptin decreases together with increased serum corticosterone during fasting, what leads to reduced pro-TRH in the hypothalamic paraventricular nucleus, with a consequent decrease of serum TSH (Legradi et al. 1997, Ahima et al. 2000, Coppola et al. 2005). However, decreased D1 activity could also contribute to the lower serum $\mathrm{T}_{3}$ found during caloric deprivation. It has not been established to what extent the peripheral reduction of $\mathrm{T}_{3}$ production could also be relevant for the decreased RMR and increased resistance to further weight loss. Conjugation of thyroid hormones involves glucuronidation or sulfation of the phenolic hydroxyl group, which increases its water solubility and facilitates urinary and biliary clearance (De Herder et al. 1988, Burchell \& Coughtrie 1989). Sulfation also promotes the inactivation of thyroid hormones, because the inner ring deiodination of sulfated $\mathrm{T}_{4}$ and $\mathrm{T}_{3}$ by $\mathrm{D} 1$ is accelerated 40- to 200-fold, whereas the outer ring deiodination of sulfated $\mathrm{T}_{4}$ is completely blocked (Visser 1994). This mechanism might be implicated in the drop of serum $T_{3}$ levels by as much as $33 \%$ in subjects submitted to weight loss programs (Rosenbaum et al. 2000).

During FR, the use of both $T_{4}$ doses increased serum $T_{4}$ concentrations in a dose-dependent manner. However, serum $\mathrm{T}_{3}$ did not increase accordingly, despite the fact that type 1 deiodinase activity was increased. Considering the fact that $\mathrm{T}_{4}$ might be deiodinated in the outer or inner rings, sulfated or glucuronidated in the liver, the respective products to be formed are: $T_{3}$, reverse $T_{3}$, sulfated $T_{3}$ or sulfated $r T_{3}$, and others. During food restriction $\mathrm{T}_{4}$ sulfation seems to increase. Maglich et al. (2004), have shown that during energy deprivation the main product of type 1 deiodinase is not $T_{3}$ as the outer ring deiodination of sulfated $\mathrm{T}_{4}$ is almost undetectable, whereas the rate of inner ring deiodination increases over 130-fold increasing the production of sulfated $\mathrm{rT}_{3}$. Recently, Emi et al. (2007) have demonstrated that the transcription and activity of rat uridine diphosphateglucuronosyltransferase $1 \mathrm{~A} 7$ is positively regulated by $\mathrm{T}_{4}$, and the enzyme in turn metabolizes and inactivates $T_{4}$. To date, the regulation of uridine diphosphate-glucuronosyltransferase 1A7 during food restriction has not been determined, but it is tempting to speculate whether under calorific restriction it could be more sensitive to serum $\mathrm{T}_{4}$ variations. Thus, injected $\mathrm{T}_{4}$ could be converted into metabolites other than $T_{3}$ during food restriction, as the same dose of $\mathrm{T}_{4}$ administered to normal rats had indeed increased serum $T_{3}$ as expected, different from what was found in FR animals. We can only hypothesize that during calorific restriction, liver metabolization of $\mathrm{T}_{4}$ and $\mathrm{T}_{3}$ is largely regulated and might be responsible for the lower serum $T_{3}$ due to increased clearance of these hormones.

Our findings show that decreased liver D1 activity is a consequence rather than the cause of decreased serum $\mathrm{T}_{3}$ during food restriction. Moreover, normalization of serum $\mathrm{T}_{4}$ and $\mathrm{T}_{3}$ in $\mathrm{FR}$ rats led to a significant decrease in protein and carcass fat contents, showing unequivocally the deleterious effects of any strategy to normalize these hormones during calorie deprivation with the aim of body weight control.

We conclude that decreased serum $\mathrm{T}_{4}$ during calorie restriction is a protective mechanism to avoid body protein loss. Other strategies such as the use of thyroid hormone analogs that might spare body protein are of great importance.

\section{Declaration of Interest}

The authors declare that there is no conflict of interest that would prejudice the impartiality of this scientific work.

\section{Funding}

This work was supported by grants from Fundação Carlos Chagas Filho de Amparo à Pesquisa do Estado do Rio de 
Janeiro (FAPERJ), Programa de Núcleos de Excelência (PRONEX/FAPERJ), and Conselho Nacional de Desenvolvimento Científico e Tecnológico (CNPq).

\section{Acknowledgements}

We are grateful for the technical assistance of Norma Lima de Araújo Faria, Advaldo Nunes Bezerra, and Wagner Nunes Bezerra. Renata Lopes Araujo and Norma Lima de Araújo Faria were recipients of fellowships from $\mathrm{CNPq}$ during the present study.

\section{References}

Aceves C, Escobar C, Rojas-Huidobro R, Vazquez-Martinez O, MartinezMerlos T, Aguilar-Roblero R \& Diaz-Munoz M 2003 Liver 5'-deiodinase activity is modified in rats under restricted feeding schedules: evidence for post-translational regulation. Journal of Endocrinology 179 91-96.

Ahima RS 2000 Leptin and neuroendocrinology of fasting. Frontiers of Hormone Research 26 42-56.

Ahima RS, Saper CB, Flier JS \& Elmquist JK 2000 Leptin regulation of neuroendocrine systems. Frontiers in Neuroendocrinology 21 263-307.

Aranda A, Montoya E \& Herrera E 1972 Effects of hypo- and hyperthyroidism on liver composition, blood glucose, ketone bodies and insulin in the male rat. Biochemistry Journal 128 597-604.

Berry MJ, Banu L \& Larsen PR 1991 Type 1 iodothyronine deiodinase is a selenocysteine-containing enzyme. Nature 349 438-440.

Bianco AC, Salvatore D, Gereben B, Berry MJ \& Larsen PR 2002 Biochemistry, cellular and molecular biology, and physiological roles of the iodothyronine selenodeiodinases. Endocrine Reviews 23 38-89.

Bradford MM 1976 A rapid and sensitive method for the quantification of microgram quantitties of protein utilizing the principle of protein dye binding. Analytical Biochemistry 72 248-254.

Bray GA, Melvin KEW \& Chopra IJ 1973 Effect of triiodothyronine on some metabolic responses of obese patients. American Journal of Clinical Nutrition 26 715-721.

Burchell B \& Coughtrie MW 1989 UDP-glucuronosyltransferases. Pharmacology and Therapentics 43 261-289.

Burini R, Santidrian S, Moreyra M, Brown P, Munro HN \& Young VR 1981 Interaction of thyroid status and diet on muscle protein breakdown in the rat, as measured by N tau-methylhistidine. Metabolism 30 679-687.

Coppola A, Meli R \& Diano S 2005 Inverse shift in circulating corticosterone and leptin levels elevates hypothalamic type 2 in fasted rats. Endocrinology $1462827-2833$.

Davidson RT, Arias EB \& Cartee GD 2002 Calorie restriction increases muscle insulin action but not IRS-1, IRS-2, or phosphotyrosine-PI 3-kinase. American Journal of Physiology. Endocrinology and Metabolism 282 270-276.

Dean DJ, Gazdag AC, Wetter TJ \& Cartee GD 1998 Comparison of the effects of 20 days and 15 months of calorie restriction on male Fischer 344 rats. Aging 10 303-307.

Douyon L \& Schteingart DE 2002 Effect of obesity and starvation on thyroid hormone, growth hormone, and cortisol secretion. Endocrinology and Metabolism Clinics of North America 31 173-189.

Emi Y, Ikushiro S \& Kato Y 2007 Thyroxine-metabolizing rat uridine diphosphate-glucuronosyltransferase $1 \mathrm{~A} 7$ is regulated by thyroid hormone receptor. Endocrinology 148 6124-6133.

Fortunato RS, Marassi MP, Chaves EA, Nascimento JH, Rosenthal D \& Carvalho DP 2006 Chronic administration of anabolic androgenic steroid alters murine thyroid function. Medicine and Science in Sports and Exercise 38 256-261.

Gardner DF, Kaplan MM, Stanley CA \& Utiger RD 1979 Effect of triiodothyronine on the metabolic and pituitary responses to starvation. New England Journal of Medicine 300 579-584.

Gazdag AC, Dumke CL, Kahn R \& Cartee GD 1999 Calorie restriction increases insulin-stimulated glucose transport in skeletal muscle from IRS-1 knockout mice. Diabetes 48 1930-1936.
Harris SB, Gunion MW, Rosenthal MJ \& Walford RL 1994 Serum glicose tolerance, corticosterone and free fatty acids during aging in energy restricted mice. Mechanisms of Ageing and Development 73 209-221.

De Herder WW, Bonthuis F, Rutgers M, Otten MH, Hazenberg MP \& Visser TJ 1988 Effects of inhibition of type 1 iodothyronine deiodinase and phenol sulfotransferase on the biliary clearance of triiodothyronine in rats. Endocrinology 122 153-157.

Kelley DE, Wing R, Buonocore C, Sturis J, Polonsky K \& Fitzsimmons M 1993 Relative effects of calorie restriction and weight loss in noninsulindepedent diabetes mellitus. Journal of Clinical Endocrinology and Metabolism $\mathbf{7 7}$ 1287-1293.

Kemnitz JW, Roecker EB, Weindruch R, Elson DF, Baum ST \& Bergman RN 1994 Dietary restriction increases insulin sensitivy and lowers blood glucose in rhesus monkeys. American Journal of Physiology 266 E540-E547.

Kinlaw WB, Schwatz HL \& Oppenheimer JH 1985 Decreased serum triiodothyronine in starving rats is due primarily to diminished thyroidal secretion of thyroxine. Journal of Clinical Investigation 75 1238-1241.

Klein I \& Ojamaa K 2001 Thyroid hormone and the cardiovascular system. New England Journal of Medicine 344 501-509.

Krotkiewski M 2000 Thyroid hormones and treatment of obesity. International Journal of Obesity 24 S116-S119.

Lanni A, Moreno M, Lombardi A, de Lange P, Silvestri E, Ragni M, Farina P, Baccari GC, Fallahi P, Antonelli A et al. 2005 3,5-diiodo-L-thyronine powerfully reduces adiposity in rats by increasing the burning of fats. FASEB Journal 19 1552-1554.

Legradi G, Emerson CH, Ahima RS, Flier JS \& Lechan RM 1997 Leptin prevents fasting-induced suppression of prothyrotropin-releasing hormone messenger ribonucleic acid in neurons of the hypothalamic paraventricular nucleus. Endocrinology 138 2569-2576.

Lowry OH, Rosebrought NJ, Farr AL \& Randall RJ 1951 Protein measurement with the Folin phenol reagent. Journal of Biological Chemistry $193265-275$.

Maglich JM, Watson J, Mcmillen PJ, Goodwin B, Willson TM \& Moore JT 2004 The nuclear receptor CAR is a regulator of thyroid hormone metabolism during caloric restriction. Journal of Biological Chemistry 279 19832-19838.

Moreno M, Lombardi A, De Lange P, Silvestri E, Ragni M, Lanni A \& Goglia F 2003 Fasting, lipid metabolism, and triiodothyronine in rat gastrocnemius muscle: interrelated roles of uncoupling protein 3 , mitochondrial thioesterase, and coenzyme Q. FASEB Journal 17 1112-1114.

Müller MJ \& Seitz HJ 1980 In vivo glucose turnover in hypo- and hyperthyroid starved rat. Pflugers Archiv 386 47-52.

Oh SS \& Kaplan ML 1994 Early treatment of obese (ob/ob) mice with triiodothyronine increases oxygen consumption and temperature and decreases body fat content. Proceedings of the Society for Experimental Biology and Medicine 207 260-267.

Okajima F \& Ui M 1979 Metabolism of glucose in hypo- and hyper-thyroid rats in vivo. Biochemical Journal 182 565-575.

O'Mara BA, Dittrich W, Lauterio TJ \& St Germain DL 1993 Pretranslational regulation of type I $5^{\prime}$-deiodinase by thyroid hormones and in fasted and diabetic rats. Endocrinology 133 1715-1723.

Ortiga-Carvalho TM, Polak J, McCann S \& Pazos-Moura CC 1996 Effect of thyroid hormones on pituitary neuromedin $\mathrm{B}$ and possible interaction between thyroid hormones and neuromedin B on thyrotropin secretion. Regulatory Peptides 14 47-53.

Ravucin E, Burnand B, Schutz Y \& Jéquier E 1985 Energy expenditure before and during energy restriction in obese. American Journal of Clinical Nutrition 41 753-759.

Rosenbaum M, Hirsch J, Murphy E \& Leibel RL 2000 Effects of changes in body weight on carbohydrate metabolism, catecholamine excretion, and thyroid function. American Journal of Clinical Nutrition 71 1421-1432.

Rosenbaum M, Murphy EM, Heymsfield SB, Matthews DE \& Leibel RL 2002 Low dose leptin administration reverses effects of sustained weightreduction on energy expenditure and circulating concentrations of thyroid hormones. Journal of Clinical Endocrinology and Metabolism 87 2391-2394.

Salih MA, Herbert DC \& Kalu DN 1993 Evaluation of the molecular and cellular basis for the modulation of thyroid c-cell hormones by aging and food restricton. Mechanisms of Ageing and Development 70 1-21. 
Scriba PC, Bauer M, Emmert D, Fateh-Moghadam A, Hofmann GG, Horn K \& Pickardt CR 1979 Effects of obesity, total fasting and re-alimentation on L-thyroxine (T4), 3,5,3'-L-triiodothyronine (T3), 3,3',5'-L-triiodothyronine (rT3), thyroxine binding globulin (TBG), cortisol, thyrotrophin, cortisol binding globulin (CBG), transferrin, alpha 2-haptoglobin and complement $C^{\prime} 3$ in serum. Acta Endocrinologica 91 629-643.

St Germain DL \& Galton VA 1985 Comparative study of pituitary-thyroid hormone economy in fasting and hypothyroid rats. Journal of Clinical Investigation 75 679-688.

Toste FB, de Moura EG, Lisboa PC, Fagundes AT, de Oliveira E \& Passos MCF 2006 Neonatal leptin treatment programmes leptin hypothalamic resistance and intermediary metabolic parameters in adult rats. British Journal of Nutrition 95 830-837.

Vagenakis AG, Portnay GI, O’Brien JT, Rudolph M, Arky A, Ingbar SH \& Braverman LE 1977 Effects of starvation on the production on metabolism of thyronixe and triiodothyronine in euthyroid obese pacients. Journal of Clinical Endocrinology and Metabolism 45 1305-1309.
Villicev CM, Freitas FR, Aoki MS, Taffarel C, Scanlan TS, Moriscot AS, Ribeiro MO, Bianco AC \& Gouveia CH 2007 Thyroid hormone receptor beta-specific agonist GC-1 increases energy expenditure and prevents fatmass accumulation in rats. Journal of Endocrinology 193 21-29.

Visser TJ 1994 Role of sulfation in thyroid hormone metabolism. Chemical Biological Interactions 92 293-303.

Wilson JH \& Lamberts SW 1981 The effect of triiodothyronine on weight loss and nitrogen balance of obese patients on a very-low-calorie liquid-formula diet. International Journal of Obesity 5 279-282.

Received in final form 14 April 2008

Accepted 21 April 2008

Made available online as an Accepted Preprint 21 April 2008 